\title{
Evaluation of heavy metals in selected fruits in Umuahia market, Nigeria: Associating toxicity to effect for improved metal risk assessment
}

\author{
Uroko Robert Ikechukwu ${ }^{1}$, Victor Eshu Okpashi²*, Uchenna Nancy Oluomachi ${ }^{1}$, Nwuke Chunedu Paulinus ${ }^{1}$, \\ Nduka Florence Obiageli ${ }^{3}$, Ogbonnaya Precious ${ }^{1}$ \\ ${ }^{1}$ Department of Biochemistry, Michael Okpara University of Agriculture Umudike, Nigeria, ${ }^{2}$ Department of Chemical Science, Cross River University of \\ Technology, Calabar, Nigeria, ${ }^{3}$ Department of Applied Sciences, Federal College of Dental Technology and Therapy, Enugu, Nigeria
}

\section{ARTICLE INFO}

Article history:

Received on: November 23, 2018

Accepted on: January 09, 2019

Available online: July 04, 2019

Key words:

Risk assessment,

Fruits,

Heavy metals,

Public health

\section{ABSTRACT}

The cases of metabolic disorder and diseases have been linked to the toxicity of heavy metals in foods crops. This study evaluates the degree of heavy metals in selected fruits sold at Umuahia market in Nigeria. Ten different fruits were randomly selected. The fresh fruits comprised Solanum lycopersicum (Tomatoes), Cucumis sativus (Cucumber), Solanum melongena (Nigerian Egggarden), Citrullus lanatus (Watermelon), Dacryodes edulis (African bush pear), Juglans regia (Walnut), Syzgium malaccense (Mountain apple), Annona muricata (Soursop), Pachycarpa kschum (Monkey kola), and Dennettia tripetala (Pepper fruit), respectively. These fruits were slices to pieces and air dried; they were ground and digested. The heavy metals were screened with atomic absorption spectrophotometer. Their health risk assessment was analyzed based on established models. Results showed that zinc and lead were undetected in fruits such as C. sativus, S. melongena, C. lanatus, D. edulis, S. malaccense, S. melongena, J. regia, A. muricata, P. kschum, and D. tripetala. Nickel was undetected in S. melongena, J. regia, A. muricata, P. kschum, and D. tripetala and the absence of cobalt in C. lanatus and J. regia. The concentration of copper, chromium $(\mathrm{Cr})$, and cadmium $(\mathrm{Cd})$ was higher compared to their respective permissible limits in fruits. Iron concentration was $2.914 \pm 0.002 \mathrm{ppm}$ in $P$. kschum, with the fruits hazard index less than one (0.3434). $\mathrm{Cr}$ and $\mathrm{Cd}$ concentration falls within tolerance level in all the fruits with acceptable cancer risk $-\left(<10^{-6}\right)$. Total cancer risks of the fruits were $>10^{-6}$, suggesting zero chance of developing cancer. This study suggests that most fruits are unsafe for human consumption and consumers should proffer a method of reducing the level of heavy metals in fruits.

\section{INTRODUCTION}

On the whole, heavy metals are best defined as metals with a specific density $>5 \mathrm{~g} / \mathrm{cm}^{3}$ and can affect the environment and living organisms' adversely [1]. Some heavy metals such as - arsenic (As), cadmium $(\mathrm{Cd})$, mercury $(\mathrm{Hg})$, and lead $(\mathrm{Pb})$ can be toxic and detrimental to health even at trace concentrations [2]. There is no argument suggesting that other heavy metals such as copper $(\mathrm{Cu})$, chromium $(\mathrm{Cr})$, molybdenum, nickel $(\mathrm{Ni})$, selenium, and zinc $(\mathrm{Zn})$ forms important constituents in diets/foods for plants and humans. Perhaps, this can be beneficial if the metal elements are present in moderate amount. Fruits form an important part of human diets due to the composition of carbohydrates, proteins, vitamins, minerals, and trace elements [3]. The contamination of fruits with heavy metals from the soil and atmosphere question

\footnotetext{
*Corresponding Authors

Victor Eshu Okpashi,

Department of Chemical Science,

Cross River University of Technology, Calabar,

Nigeria. Email: vic2reshu@gmail.com
}

their quality and safety [4]. The consumption/ingestion of fruits with high concentrations of heavy metals $(\mathrm{Ar}, \mathrm{Cu}, \mathrm{Cd}$, and $\mathrm{Pb}$ ) has been implicated in the causation of gastrointestinal cancer [5]. Other anthropogenic sources such as waste incineration, industrial processes, and vehicular traffic emit heavy metals into the atmosphere [6].

The consumption/ingestion of contaminated fruits is the direct route where humans and animals are exposed to heavy metal $[7,8]$. Abandoned waste dumpsites have been used extensively for the cultivation of fruits crops. Furthermore, research has shown that fruits are capable of accumulating high levels of heavy metals from polluted soils through translocation [9]. It will be of great benefit if one appreciates that heavy metals are persistent and nonbiodegradable [10]. They might be transported from soil to ground waters or taken up by crops. Based on this premise, the knowledge about metals to plants interactions is important for environmental safety and human health risk [2]. There has been an increasing quest for determining heavy metal levels in public food supplied. Though, heavy metals concentration in bio-available form may not be proportional to the total concentration in the soil ecology, that is 
because some of the heavy metals are either transform or found in combined state that render them inactive $[11,12]$.

There has been loud and persuasive advocacy about the benefits of consuming foods from plants sources, especially fruits from the public health sector. In carrying out this advocacy, nobody was able to give a corresponding explanation about the health effect of ingesting toxic constituents in the fruits. At present, there is no regulation on the quality of fruits sold in most of Nigeria markets. It is well understood that the irrigation of crops (fruits) with pharmaceutical effluents, industrial discharges, and domestic wastewater has enriched the soils with heavy metals. Heavy metals are toxic to humans and consumption of these contaminated fruits could result in a much human health risk.

An elevated dietary iron intake enhances the incidence of carcinogeninduced mammary tumors in rats and estrogen-induced kidney tumors in Syrian hamsters [13]. Estrogen administration increases iron accumulation in hamsters and facilitates iron uptake by cells in culture. In humans, increased body stores of iron have been shown to increase the risk of several estrogen-induced cancers [14]. Increased incidence of congenital malformations in infants has also been associated with Zn deficiency in lactating mothers [15].

$\mathrm{Pb}$ toxicity has been linked to low intelligent quotients in children and found to affects several organs and systems - blood, central nervous system, kidneys, reproductive, and immune systems [16]. Cd in the body is known to affect the renal tubules and causes damage that results in proteinuria. $\mathrm{Cd}$ affects the enzymes responsible for reabsorption of proteins in kidney tubules [17], Cd reduces the activity of deltaaminolevulinic acid synthetase, arylsulfatase, alcohol dehydrogenase, and lipoamide dehydrogenase, respectively. $\mathrm{Cr}$ is associated with allergic dermatitis in humans [18]. Furthermore, hazard identification of biochemical and physical agents ensures that particular food or group of foods is free from substances that may induce negative health consequence. Hazard identification as it is applied to metals toxicity, aimed at evaluating the weight of evidence on post consumption of selected edible fruits to ascertain the extent of health risk on humans [19]. This judgment provides a quantitative/qualitative estimate of risk. It is established health-based guidance values such as - Acceptable Daily Intake (ADI) and Tolerable Daily Intake (TDI). This form the index where human exposure is considered to be without appreciable health risk [20]. We carry out this study to evaluate perceived human health risk associated with the consumption of fruits.

\section{MATERIALS AND METHODS}

\subsection{Fruits}

Ten edible fruits were used in this study - Solanum lycopersicum (Tomatoes), Cucumis sativus (Cucumber), Solanum melongena (Nigerian Egggarden), Citrullus lanatus (Watermelon), Dacryodes edulis (African bush pear), Juglans regia (Walnut), Syzgium malaccense (Mountain apple), Annona muricata (Soursop), Pachycarpa kschum (Monkey kola), and Dennettia tripetala (Pepper fruit).

\subsubsection{Chemicals/Reagents}

The chemicals and reagents used in the study were of analytical grade and were sourced from chemical stores in Onitsha market, Anambra State and Multiuser Laboratory at the Department of Chemistry, Ahmadu Bello University Zaria.

\subsubsection{Collection of fruit samples}

Ten fruits were bought from Ubani market in Umuahia, Abia State, Nigeria. Ubani market is a centralized modern market in Umuahia where people come to buy and sell goods.

\subsubsection{Preparation of fruit samples}

The fruits samples were washed thoroughly with tap water followed by distilled water to remove adsorbed elements (pollutants). Samples were cut into small pieces and air dried for $48 \mathrm{~h}$ in a hot air oven at $100^{\circ} \mathrm{C} \pm 1{ }^{\circ} \mathrm{C}$. Dried samples were pulverized to a fine powder and sieved with a $1 \mathrm{~mm}$ mesh. Each fruit sample was labeled $\left(\mathrm{D}_{1}-\mathrm{D}_{10}\right)$. They were stored in a dry plastic container.

\subsubsection{Digestion of fruits samples}

To each fruit sample, $0.5 \mathrm{~g}$ of dried sample was digested with $\mathrm{HNO}_{3}$, and $\mathrm{HClO}_{4}$, in a 5:1 ratio until a transparent solution was obtained as described by World Health Organization/Food and Agriculture Organization [21]. The fruit digests were filtered and diluted to $25 \mathrm{ml}$ with distilled water. The heavy metals in the acid digests of fruit samples were analyzed with atomic adsorption spectrophotometer (AAS).

\subsubsection{Calibration of $A A S$}

Standard solutions of the heavy metals, namely $\mathrm{Pb}, \mathrm{Cd}$, and $\mathrm{Cu}$, cobalt (Co), Ni, and Zn, were purchased from Merck (Darmstadt, Germany). The standards reagents were prepared from the individual $1000 \mathrm{mg} / \mathrm{l}$

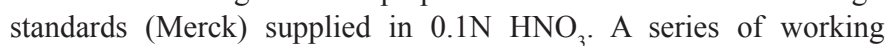
standards were prepared from these standard reagents.

\subsection{Determination of Heavy Metal Concentration in Fruit Samples}

The concentration of heavy metals was analyzed using atomic absorption spectrophotometer, (Thermo Scientific Pvt. Ltd. India Model No. AA 303). A double beam and deuterium background hollow cathode lamps of $\mathrm{Fe}, \mathrm{Pb}, \mathrm{Cd}, \mathrm{Zn}$, and $\mathrm{Cu}$ was used at specific wavelengths. All samples were run in triplicates.

\subsection{Determination of Daily Intake of Heavy Metals (DIM)}

The DIM were determined using the method of Ali et al. [22]. DIM was calculated using equation 1 .

\subsubsection{DIM}

$$
\mathrm{DIM}=\frac{\mathrm{C}_{\text {metal }} \times \mathrm{D}_{\text {vegetables/furit intake }}}{\mathrm{B}_{\text {Waverage }}} \quad \text { Equation } 1
$$

Where: $\mathrm{C}_{\text {metal }}$ is the metal concentration in vegetable in $\mathrm{mg} / \mathrm{kg}$.

$D_{\text {frruits }}$ intake is the daily intake of fruit/vegetable $(300 \mathrm{~g} / \mathrm{kg} / \mathrm{day})$ (WHO, 2018).

$\mathrm{B}_{\text {Waverage }}$ is the average body weight of a Nigerian $62 \mathrm{~kg}$ (WHO, 2018).

\subsection{Determination of Non-Carcinogenic Risk (CR) Index}

The non- CR assessments are conducted to estimate the potential health risks of pollutants using the target hazard quotient (THQ). The THQ values through the consumption of fruits were analyzed for each heavy metal, while the calculations were computed using the standard assumption for an integrated [23] risk analysis in line with Equation 2.

$$
\mathrm{THQ}=\frac{\mathrm{DIM}}{\mathrm{RfD}}
$$

Equation 2

Where: DIM is the DIMs ( $\mathrm{Mg} / \mathrm{Kg} /$ person)

Reference dose (RfD) is the oral reference dose ( $\mathrm{mg} / \mathrm{kg} / \mathrm{d})$.

RfDs are based on 0.04, 0.02, 0.03, 0.7, 0.003, 0.001, 0.014, 0.3, and $0.004 \mathrm{mg} / \mathrm{kg} /$ day for $\mathrm{Cu}, \mathrm{Ni}, \mathrm{Co}, \mathrm{Fe}, \mathrm{Cr}, \mathrm{Cd}, \mathrm{Mn}, \mathrm{Zn}$, and $\mathrm{Pb}$, respectively [23]. 
If the THQ value is equal to or $>1$, there is a potential health risk, and related $<1$, the exposed population is unlikely to experience any adverse health hazard. Conversely, if the THQ is interventions and protective measurements should be taken [24].

\subsection{Determination of Hazard Index (HI)}

To estimate the risk to human health through more than one heavy metal the concept of hazard index (HI) was initiated. The HI is the sum of the HQ for all HMs, which was calculated by the Equation 3 [25].

$\mathrm{HI}=\sum \mathrm{THQ}=\mathrm{THQ}_{\mathrm{Cu}}+\mathrm{THQ}_{\mathrm{Ni}}+\mathrm{THQ}_{\mathrm{Co}}+\mathrm{THQ}_{\mathrm{Fe}}+\mathrm{THQ}_{\mathrm{Cr}}+\mathrm{THQ}_{\mathrm{Cd}}+\mathrm{THQ}_{\mathrm{Mn}}$ $\begin{array}{ll}+\mathrm{THQ}_{\mathrm{Zn}}+\mathrm{THQ}_{\mathrm{Pb}} & \text { Equation } 3\end{array}$

Where: $\mathrm{HI}=$ Hazard Index

THQ $=$ Target HQ

HQ for the locals (consumers) through the consumption of contaminated fruits were analyzed by finding the ratio of DIM to the oral RfD (for each metal). If the value of HQ is $<1$, then the exposed local population (consumers) is said to be safe if $\mathrm{HQ}$ is equal to or $>1$, it is considered unsafe for human health.

\subsection{Determination of CR Index}

CR indicates an incremental probability of an individual to developing cancer over a lifetime due to exposure to a potential carcinogen. Cancer risk over a lifetime exposure to $\mathrm{Ni}, \mathrm{Cr}, \mathrm{Cd}$, and $\mathrm{Pb}$ was obtained by equation 4 using cancer slope factor (CSF).

$$
\mathrm{CR}=\mathrm{CSF} \times \mathrm{EDI}
$$

Equation 4

Where: CSF is the oral carcinogenic slope factor of $0.0085,0.38$, 0.5 , and $1.7(\mathrm{mg} / \mathrm{kg} / \mathrm{day})$ for $\mathrm{Pb}, \mathrm{Cd}, \mathrm{Cr}$, and $\mathrm{Ni}$, respectively, and $1.5(\mathrm{mg} / \mathrm{kg} /$ day $)$ for as set by USEPA [23]. EDI is the estimated DIM. Acceptable risk levels for carcinogens range from $10^{-4}$ (risk of developing cancer over a human lifetime is 1 in 10,000 ) to $10^{-6}$ (risk of developing cancer over a human lifetime is 1 in 1,000,000).

\subsection{Determination of Total CR}

The cumulative cancer risk due to exposure to multiple sources of carcinogenic heavy metals through consumption of a particular type of fruit and was assumed, and the sum of the individual heavy metal increment risk was calculate following equation 5 [26].

$$
\text { Total cancer risk }=\sum \mathrm{CR}
$$

Equation 5

Where CR is the cancer risk.

\subsection{Statistical Analysis}

The data were subjected to One-way analysis of variance. Significant differences were accepted at $P<0.05$. Results are expressed in means \pm standard errors of means. The analysis was computed using Statistical Product and Service Solutions software version 22.

\section{DISCUSSION}

Heavy metals are considered the most important constituents of pollution from the terrestrial environment due to toxicity, partitioning in the soil, and accumulation in plants [27]. Results in Table 1 show the concentration of heavy metals in fruits sold at Ubani market against together with their respective permissible limits. It was observed that the concentration of $\mathrm{Cd}$ in the fruits was above the permissible limit $(0.001 \pm 0.000 \mathrm{ppm})$. Their values range from $0.033 \pm 0.002$ in C. sativus to $0.042 \pm 0.001$ in D. tripetala. $\mathrm{Cr}$ and $\mathrm{Cu}$ concentration was also above the permissible limits $0.003 \pm 0.000$ and $0.010 \pm 0.000$, respectively, an exception of $A$. maricata where its $\mathrm{Cr}$ concentration was not detected. It was further observed that the concentration of iron and manganese was below their respective permissible limit $-5.000 \pm 0.000$ and 0.300 \pm 0.000 . Ni and Co concentration was also below their respective permissible limits. However, S. melongena, J. regia, Amuricata, $P$. kschum, and D. tripetala had no detectable concentration of Co, while Co concentration in $S$. melongena and A. muricata had no concentration. The concentration of $\mathrm{Zn}$ and $\mathrm{Pb}$ was not detected, an exception of J. regia $(0.001 \pm 0.000)-\mathrm{Zn}$ concentration, which was below the permissible limit $(2.000 \pm 0.000 \mathrm{mg} / \mathrm{kg})$. Toxic metals are commonly found in foods, drinking water, and air [28,29]. Metal poisoning occurs due to an accumulation of toxic metals in the body. Metals become toxic when the quantity is reasonably high such that its concentration may reason injury to the target cells. Heavy metals such as mercury, $\mathrm{Pb}$, and $\mathrm{Cd}$ are mostly considered to elicit effective harmfulness to cells [29]. They cause damage at the cellular level by initiating oxidative stress, which is attributed to the causation/development of many diseases condition including mental retardation [30].

Heavy metals are included in many fertilizers and pesticides as micronutritional or biocidal components; they may be represented as naturally occurring contaminants. Most of the fruits samples collected from Ubani market contained detectable levels of the studied heavy metals. The accumulation of these heavy metals in fruits and vegetables may suggest health risk to the consumers, especially for a population with high consumption rates [31]. Thus, estimating daily intake or "tolerable intake" is widely used to describe safety levels of intake of heavy metals. $\mathrm{Cr}$ has been described as an essential trace element in humans and some animals [32]. The daily intake for $\mathrm{Cr}$ in this study was below the established TDI of 1.5E-01 [33]. The concentration of $\mathrm{Pb}$ and $\mathrm{Zn}$ in most fruits in Table 1 was not detected; hence, their daily intake was calculated. Some researchers reasoned that the concentration of $\mathrm{Cd}, \mathrm{Cr}$, and $\mathrm{Cu}$ in some edible fruits samples were usually above the permissible limits as listed by Gowd at al. [34]' in view of this, the route of elemental absorption and trans-location was reported by Adewole and Uchegbu [35] that fruits accumulate $\mathrm{Cd}$ from soil much more efficiently than any other heavy metals. $\mathrm{Cr}$ is a mineral found in fruits which plays a role in the metabolism of nutrients through its impact on insulin. $\mathrm{Cr}$ picolinate is the form found in dietary supplements [36]. $\mathrm{Cu}$ is also an essential micronutrient which functions as a biocatalyst and in humans, it is required for body pigmentation, and helps to maintain a healthy central nervous system and prevent anemia [3]. However, slight increases in the levels of $\mathrm{Cu}$ and $\mathrm{Cr}$ (beyond the permissible limits) may interfere with physiological processes. For instance, chronic exposure to $\mathrm{Cu}$ and $\mathrm{Cr}$ can damage the liver and kidney [35]. The data in Table 2 show the DIM in fruit sold in Ubani market. It was observed that the daily intake of $\mathrm{Cd}$ in all the fruits was below the TDI (4.0E- $02 \mathrm{mg} / \mathrm{kg} /$ day) in D. edulis and $C$. sativus having the highest and least values of daily intake of $\mathrm{Ni}$ from $S$. melongena, J. regia, A. muricata, $P$. kschum, and D. tripetala, respectively. However, the daily intake of $\mathrm{Ni}$ from $S$. lycopersicum, $C$. sativus, $C$. lunatus, $D$. edulis, and $S$. malaceense, respectively, was below the TDI of $\mathrm{Ni}(2.0 \mathrm{E}-02 \mathrm{mg} / \mathrm{kg} /$ day $)$. Their ranges vary from $4.5 \mathrm{E}-$ $05 \mathrm{mg} / \mathrm{kg} /$ day in C. lanatus to 3.3E-04 in D. edulis. It was also recorded that with the exception of $C$. lanatus and A. muricata which indicates no daily intake of $\mathrm{Co}$, other fruits indicated that the daily intake of $\mathrm{Co}$ from their consumption was below the TDI which varies from 5.0E-05 (mg/kg/day) in P. kschum to $4.1 \mathrm{E}-02(\mathrm{mg} / \mathrm{kg} /$ day) in $S$. lycopersium.

THQ through the consumption of fruits and vegetables is a measure of chemical contaminants. It is not a measure of risk but indicates a level 
Table 1: Heavy metals in fruits sold at Ubani Market in Umuahia, against their respective permissible limits in fruits

\begin{tabular}{|c|c|c|c|c|c|c|c|c|c|}
\hline Edible fruits & $\mathrm{Cu}(\mathrm{ppm})$ & $\mathrm{Ni}(\mathrm{ppm})$ & Co (ppm) & Iron (ppm) & $\mathrm{Cr}$ (ppm) & Cd (ppm) & Manganese (ppm) & $\mathrm{Zn}$ (ppm) & $\mathrm{Pb}$ (ppm) \\
\hline Permissible limits & $0.010 \pm 0.000^{\mathrm{a}}$ & $0.020 \pm 0.000^{\mathrm{d}}$ & $2.000 \pm 0.000^{\mathrm{h}}$ & $5.000 \pm 0.000^{\mathrm{j}}$ & $0.003 \pm 0.000^{\mathrm{a}}$ & $0.001 \pm 0.000^{\mathrm{a}}$ & $0.300 \pm 0.000^{\mathrm{h}}$ & $2.000 \pm 0.000^{\mathrm{b}}$ & $0.010 \pm 0.000$ \\
\hline S. lycopersicum & $0.106 \pm 0.002^{\mathrm{bc}}$ & $0.013 \pm 0.002^{\mathrm{c}}$ & $0.072 \pm 0.001^{\mathrm{f}}$ & $2.447 \pm 0.010^{\mathrm{f}}$ & $0.122 \pm 0.001^{\mathrm{g}}$ & $0.035 \pm 0.003^{\mathrm{bc}}$ & $0.074 \pm 0.000^{\mathrm{f}}$ & ND & ND \\
\hline S. melongena & $0.101 \pm 0.001^{\mathrm{bc}}$ & ND & $0.020 \pm 0.001^{\mathrm{b}}$ & $2.571 \pm 0.001^{\mathrm{g}}$ & $0.138 \pm 0.002^{\mathrm{h}}$ & $0.034 \pm 0.001^{\mathrm{bc}}$ & $0.093 \pm 0.002^{\mathrm{g}}$ & ND & ND \\
\hline C. lanatus & $0.102 \pm 0.001^{\mathrm{bc}}$ & $0.007 \pm 0.001^{\mathrm{a}}$ & ND & $2.283 \pm 0.002^{\mathrm{d}}$ & $0.017 \pm 0.002^{\mathrm{b}}$ & $0.035 \pm 0.001^{\mathrm{bc}}$ & $0.039 \pm 0.002^{\mathrm{d}}$ & ND & ND \\
\hline D. edulis & $0.147 \pm 0.001^{\mathrm{d}}$ & $0.051 \pm 0.001^{\mathrm{f}}$ & $0.032 \pm 0.001^{\mathrm{d}}$ & $2.826 \pm 0.003^{\mathrm{h}}$ & $0.033 \pm 0.002^{\mathrm{c}}$ & $0.036 \pm 0.002^{\mathrm{c}}$ & $0.032 \pm 0.001^{\mathrm{bc}}$ & ND & ND \\
\hline S. malaccense & $0.103 \pm 0.001^{\mathrm{bc}}$ & $0.010 \pm 0.001^{\mathrm{b}}$ & $0.009 \pm 0.001^{\mathrm{a}}$ & $2.371 \pm 0.020^{\mathrm{e}}$ & $0.211 \pm 0.001^{\mathrm{i}}$ & $0.040 \pm 0.001^{\mathrm{de}}$ & $0.017 \pm 0.002^{\mathrm{a}}$ & ND & ND \\
\hline A. muricata & $0.099 \pm 0.001^{\mathrm{bc}}$ & ND & ND & $1.937 \pm 0.005^{\mathrm{a}}$ & ND & $0.036 \pm 0.001^{\mathrm{c}}$ & $0.018 \pm 0.001^{\mathrm{a}}$ & ND & ND \\
\hline P. kschum & $0.033 \pm 0.003^{\mathrm{a}}$ & ND & $0.083 \pm 0.001^{\mathrm{g}}$ & $2.914 \pm 0.002^{\mathrm{i}}$ & $0.322 \pm 0.001^{\mathrm{j}}$ & $0.034 \pm 0.011^{\mathrm{de}}$ & $0.030 \pm 0.002^{\mathrm{b}}$ & ND & ND \\
\hline D. tripetala & $0.121 \pm 0.056^{\mathrm{bc}}$ & ND & $0.028 \pm 0.002^{\mathrm{c}}$ & $1.970 \pm 0.020^{\mathrm{b}}$ & $0.079 \pm 0.002^{\mathrm{e}}$ & $0.042 \pm 0.001^{\mathrm{e}}$ & $0.033 \pm 0.002^{\mathrm{c}}$ & ND & ND \\
\hline
\end{tabular}

Values are presented as mean \pm standard deviation $(n=3)$ and values with different supper scripts in each of the columns are significantly $(P<0.05)$ different. ND: Not detected. S. lycopersicum: Solanum lycopersicum, C. sativus: Cucumis sativus, S. melongena: Solanum melongena, D. edulis: Dacryodes edulis, J. regia: Juglans regia, S. malaccense: Syzgium malaccense, A. muricata: Annona muricata, P. kschum: Pachycarpa kschum, D. tripetala: Dennettia tripetala, Cu: Copper, Cr: Chromium, Ni: Nickel, Zn: Zinc, Pb: Lead, Cd: Cadmium, Co: Cobalt

Table 2: DIM from fruits sold in Ubani market Umuahia $(\mathrm{mg} / \mathrm{kg} / \mathrm{day})$

\begin{tabular}{|c|c|c|c|c|c|c|c|c|c|}
\hline Fruits & $\mathrm{Cu}$ & $\mathbf{N i}$ & Co & $\mathrm{Fe}$ & $\mathrm{Cr}$ & Cd & Mn & Zn & $\mathbf{P b}$ \\
\hline S. lycopersicum & $6.8 \mathrm{E}-04$ & $8.4 \mathrm{E}-05$ & 4.7E-04 & $1.6 \mathrm{E}-02$ & $7.8 \mathrm{E}-04$ & $2.3 \mathrm{E}-04$ & 4.8E-04 & - & - \\
\hline C. sativus & 5.7E-04 & 1.7E-04 & $1.9 \mathrm{E}-04$ & $1.5 \mathrm{E}-02$ & $3.9 \mathrm{E}-04$ & $2.1 \mathrm{E}-04$ & $5.0 \mathrm{E}-04$ & - & - \\
\hline C. lanatus & $6.6 \mathrm{E}-04$ & $4.5 \mathrm{E}-05$ & - & $1.5 \mathrm{E}-02$ & $1.1 \mathrm{E}-04$ & $2.2 \mathrm{E}-04$ & $2.5 \mathrm{E}-04$ & - & - \\
\hline D. edulis & $9.5 \mathrm{E}-04$ & 3.3E-04 & $2.1 \mathrm{E}-04$ & $1.8 \mathrm{E}-02$ & 2.1E-04 & 2.3E-04 & 2.1E-04 & - & - \\
\hline J. regia & $8.1 \mathrm{E}-04$ & - & 4.3E-04 & $1.5 \mathrm{E}-02$ & $5.9 \mathrm{E}-04$ & $2.5 \mathrm{E}-04$ & 3.6E-04 & $6.0 \mathrm{E}-06$ & - \\
\hline A. muricata & $6.4 \mathrm{E}-04$ & - & - & 1.3E-02 & - & 2.3E-04 & $1.2 \mathrm{E}-04$ & - & - \\
\hline P. schum & $6.3 \mathrm{E}-04$ & - & $5.4 \mathrm{E}-04$ & $1.9 \mathrm{E}-02$ & $2.1 \mathrm{E}-03$ & $2.6 \mathrm{E}-04$ & $1.9 \mathrm{E}-04$ & - & - \\
\hline D. tripetala & 7.4E-04 & - & $1.8 \mathrm{E}-04$ & $1.2 \mathrm{E}-02$ & $5.1 \mathrm{E}-04$ & 2.7E-04 & 2.1E-04 & - & - \\
\hline $\mathrm{RfD}_{0}$ & $4.0 \mathrm{E}-02$ & $2.0 \mathrm{E}-02$ & $4.3 \mathrm{E}-02$ & 7.0E-01 & $15 \mathrm{E}-01$ & $1.0 \mathrm{E}-03$ & $1.4 \mathrm{E}-02$ & $3.0 \mathrm{E}-01$ & $4.0 \mathrm{E}-03$ \\
\hline
\end{tabular}

Values above the tolerable intake of each heavy metal give rise to negative health effect. S. lycopersicum: Solanum lycopersicum, C. sativus: Cucumis sativus, S. melongena: Solanum melongena, C. lanatus: Citrullus lanatus, D. edulis: Dacryodes edulis, J. regia: Juglans regia, S. malaccense: Syzgium malaccense, A. muricata: Annona muricata,

P. kschum: Pachycarpa kschum, D. tripetala: Dennettia tripetala, DIM: Daily intake of heavy metals, $\mathrm{RfD}_{\mathrm{o}}$ : oral reference dose

of concern [24]. The observed THQ of manganese was approximately 1 indicating that consumers of Aciagrion africanum, Talinum triangulare, and Gongronema latifolium from Ubani are exposed to the health risk of manganese. The fruits studied indicate no adverse health effect because the THQ is $<1$; hence, it is safe for consumption (Table 3). Li Z [37], reported that the highest THQ value poses a relatively higher potential health risk to human [37].

Results in Table 3 show the THQ of heavy metals of fruits sold at Ubani market. There was no THQ for $\mathrm{Pb}$ and $\mathrm{Zn}$, except J. regia for $\mathrm{Zn}$. A. muricata had no THQ for Cr, Co, and Ni. Furthermore, S. melongena, $J$. regia, $P$. kschum, and $D$. tripetala had no THQ for the Ni. It was observed that $\mathrm{Cu}$, iron, $\mathrm{Cd}$, and manganese had THQ in all fruits which were $<1$. The highest range of THQ was noted in $\mathrm{Cd}$ which ranged from $C$. sativus $(0.213)$ to $D$. tripetala $(0.271)$. Table 4 represents the $\mathrm{HI}$ of heavy metals of fruits sold at Ubani market. It was observed that none of the fruits had $\mathrm{HI} \geq 1$. All fruits had $\mathrm{HI}<1$, which ranges from A. muricata (0.2740) to S. lycoporsicum (0.3525). The $\mathrm{HI}$ of all fruits in Table 4 indicates no adverse health effect because the $\mathrm{HI}$ is $<1$.

The cancer risks of heavy metals in fruits sold at Ubani market is shown in Table 5. All the fruits show no high cancer risk except
P. kschum (1.1E-03) for $\mathrm{Cr}$. $\mathrm{Pb}$ indicated no cancer risk in all the studied fruits. The cancer risk of $\mathrm{Cd}$ ranges from A. muricata < $C$. sativus $<S$. melingena $<C$. lanatus $<S$. lycopersicum $=D$. edulis $<J$. regia $<S$. malaccense $=P$. kschum $<D$. tripetala. All studied fruits samples had cancer risk of $\mathrm{Cr}$ which was within the acceptable cancer risk except $A$. muricata that was not indicated. In the case of Ni, S. melongena, J. regia, A. muricata, P. kschum, and D. tripetala had no cancer risk. CR is estimated and expressed as a probability of contracting cancer over a lifetime of 70 years. The average value of cancer risk for all studied vegetables did not show carcinogenicity thereby rendering it safe for consumption. However, in comparison with established guideline values, data from this study are suggestive that $P$. kschum collected from Ubani may not be safe for consumers as it shows high cancer risk and as such consumers have the probability of contracting cancer over an extended lifetime of 70 years. An acute oral dose of $\mathrm{Zn}$ may cause symptoms such as tachycardia, vascular shock, dyspeptic nausea, vomiting, diarrhrea, pancreatitis, and damage of hepatic parenchyma cells [38]. When high levels of $\mathrm{Zn}$ are ingested, inhibition of $\mathrm{Cu}$ absorption through interaction with metallothionein at the brush border of the intestinal lumen may occur. Both $\mathrm{Cu}$ and $\mathrm{Zn}$ may bind to the same metallothionein protein, 
Table 3: THQ s of heavy metals of fruits sold in Ubani market Umuahia

\begin{tabular}{|c|c|c|c|c|c|c|c|c|c|}
\hline Fruits & $\mathrm{Cu}$ & $\mathbf{N i}$ & Co & $\mathrm{Fe}$ & $\mathrm{Cr}$ & Cd & Mn & Zn & $\mathbf{P b}$ \\
\hline S. lycopersicum & 0.017 & 0.040 & 0.011 & 0.023 & 0.0005 & 0.226 & 0.035 & - & - \\
\hline C. sativus & 0.014 & 0.009 & 0.005 & 0.021 & 0.0003 & 0.213 & 0.036 & - & - \\
\hline C. lanatus & 0.017 & 0.002 & - & 0.021 & 0.0001 & 0.219 & 0.018 & - & - \\
\hline D. edulis & 0.024 & 0.017 & 0.005 & 0.026 & 0.0001 & 0.232 & 0.015 & - & - \\
\hline A. muricata & 0.016 & - & - & 0.018 & - & 0.232 & 0.008 & - & - \\
\hline P. kschum & 0.016 & - & 0.027 & 0.027 & 0.0014 & 0.258 & 0.014 & - & - \\
\hline D. tripetala & 0.016 & - & 0.004 & 0.018 & 0.0003 & 0.271 & 0.015 & - & - \\
\hline
\end{tabular}

An $\mathrm{HQ}<1$ indicates no adverse health effects, while $\mathrm{HQ}>1$ or $=1$ indicates that adverse health effects are likely to occur. If the value of $\mathrm{HQ}$ is $<1$, then the exposed local population (consumers) is said to be safe, If HQ is equal to or $>1$, it is considered to be unsafe for human health. Therefore, the potential health risk may occur and relative interventions and protective measurements could be taken. S. lycopersicum: Solanum lycopersicum, C. sativus: Cucumis sativus, S. melongena: Solanum melongena, C. lanatus: Citrullus lanatus, D. edulis: Dacryodes edulis, J. regia: Juglans regia, S. malaccense: Syzgium malaccense, A. muricata: Annona muricata, P. kschum: Pachycarpa kschum, D. tripetala: Dennettia tripetala, THQ: Target Hazard quotient

Table 4: HI of heavy metals of fruits sold in Ubani market - Umuahia

\begin{tabular}{lc} 
Fruits & Hazard index \\
S. lycoporsicum & 0.3525 \\
C. sativus & 0.2983 \\
S. melongena & 0.3096 \\
C. lanatus & 0.2771 \\
D. edulis & 0.3191 \\
J. regia & 0.34242 \\
S. malaccense & 0.3099 \\
A. muricata & 0.2740 \\
P. kschum & 0.3434 \\
D. tripetala & 0.3243 \\
\hline
\end{tabular}

An $\mathrm{HI}<1$ indicates no adverse health effects, while $\mathrm{HI}>1$ or $=1$ indicates that adverse health effects are likely to occur. S. lycopersicum: Solanum lycopersicum, C. sativus: Cucumis sativus, S. melongena: Solanum melongena, C. lanatus: Citrullus lanatus, D. edulis: Dacryodes edulis, J. regia: Juglans regia, S. malaccense: Syzgium malaccense, A. muricata: Annona muricata, P. kschum: Pachycarpa kschum, D. tripetala: Dennettia tripetala, HI: Hazard Index

Table 5: Cancer risks of heavy metals in fruits sold at Ubani market in Umuahia

\begin{tabular}{lcccc} 
Fruits & $\mathbf{N i}$ & $\mathbf{C r}$ & $\mathbf{C d}$ & $\mathbf{P b}$ \\
S. lycopersicum & $1.4 \mathrm{E}-04$ & $3.9 \mathrm{E}-04$ & $8.7 \mathrm{E}-05$ & - \\
C. sativus & $2.9 \mathrm{E}-04$ & $2.0 \mathrm{E}-04$ & $8.0 \mathrm{E}-05$ & - \\
S. melongena & - & $8.9 \mathrm{E}-04$ & $8.4 \mathrm{E}-05$ & - \\
C. lanatus & $7.7 \mathrm{E}-05$ & $5.5 \mathrm{E}-05$ & $8.4 \mathrm{E}-05$ & - \\
D. edulis & $6.8 \mathrm{E}-04$ & $1.1 \mathrm{E}-04$ & $8.7 \mathrm{E}-05$ & - \\
J. regia & - & $3.0 \mathrm{E}-04$ & $9.5 \mathrm{E}-05$ & - \\
S. malaccense & $1.1 \mathrm{E}-04$ & $7.0 \mathrm{E}-04$ & $9.9 \mathrm{E}-05$ & - \\
A. muricata & - & - & $7.4 \mathrm{E}-05$ & - \\
P. schum & - & $1.1 \mathrm{E}-03$ & $9.9 \mathrm{E}-05$ & - \\
D. tripetala & - & $2.6 \mathrm{E}-06$ & $1.0 \mathrm{E}-04$ & - \\
\hline
\end{tabular}

The level of acceptable cancer risk (ILCR) for the regulatory purpose is considered within the range of $10^{-6}-10^{-4}$. ILCR: Incremental life cancer risk, S. lycopersicum: Solanum lycopersicum, C. sativus: Cucumis sativus, S. melongena: Solanum melongena, D. edulis: Dacryodes edulis, J. regia: Juglans regia, S. malaccense: Syzgium malaccense, A. muricata: Annona muricata,

P. schum: Pachycarpa kschum, D. tripetala: Dennettia tripetala
Table 6: Total cancer risk of heavy metals in fruits sold at Ubani market in Umuahia

\begin{tabular}{|c|c|}
\hline Fruits & Total cancer risk \\
\hline S. lycoporsicum & $14 \mathrm{E}-13$ \\
\hline C. sativus & $12.9 \mathrm{E}-13$ \\
\hline S. melongena & $17.3 \mathrm{E}-9$ \\
\hline C. lanatus & $21.6 \mathrm{E}-15$ \\
\hline D. edulis & $16.6 \mathrm{E}-13$ \\
\hline J. regia & $12.5 \mathrm{E}-9$ \\
\hline S. malaccense & $18 \mathrm{E}-13$ \\
\hline A. muricata & $7.4 \mathrm{E}-5$ \\
\hline P. schum & $11 \mathrm{E}-8$ \\
\hline D. tripetala & 3.6E-10 \\
\hline \multicolumn{2}{|c|}{$\begin{array}{l}\text { The level of acceptable cancer risk (ILCR) for the regulatory purpose } \\
\text { is considered within the range of } 10^{-6}-10^{-4} \text {. ILCR: Incremental life } \\
\text { cancer risk, S. lycopersicum: Solanum lycopersicum, C. sativus: } \\
\text { Cucumis sativus, S. melongena: Solanum melongena, C. lanatus: Citrullus lanatus, } \\
\text { D. edulis: Dacryodes edulis, J. regia: Juglans regia, S. malaccense: Syzgium } \\
\text { malaccense, A. muricata: Annona muricata, P. schum: Pachycarpa kschum, } \\
\text { D. tripetala: Dennettia tripetala }\end{array}$} \\
\hline
\end{tabular}

but $\mathrm{Cu}$ has a higher affinity for metallothionein than $\mathrm{Zn}$ and readily displaces $\mathrm{Zn}$ from metallothionein protein [39]. $\mathrm{Cu}$ complexes with metallothionein are retained in the mucosal cell, relatively unavailable to be transferred to the plasma, and can be excreted in feces when the mucosal cells are sloughed off. Thus, an excess of $\mathrm{Zn}$ may result in a decreased bioavailability of dietary $\mathrm{Cu}$ and the development of $\mathrm{Cu}$ deficiency [40]. On the other hand, Zn deficiency has been associated with dermatitis, anorexia, growth retardation, poor wound healing, hypogonadism with impaired reproductive capacity, impaired immune function, and depressed mental function $[41,42]$.

The analysis in Table 6 represents the total cancer risk of heavy metals in fruits sold at Ubani market. It was observed that all the fruits had its cancer risk below $10^{-6}$, - Incremental life cancer risk [ILCR] $<10^{-6}$. The fruit samples $S$. lycopersicum, $C$. sativus, $D$. edulis and $S$. malaccense were within the same range. The fruit samples - A. muricata and C. lanatus had the highest total cancer risk of $\mathrm{Pb}$. Following up with this analysis, one can infer that some of the fruits are safe, while some are unsafe for consumption. The big question is how can one identify 
a particular fruit that is laden with heavy metals? That is why this investigation was conducted to create consumer awareness to avert any possible health hazard that may arise from the consumption of/ fruit with heavy metals.

\section{CONCLUSION}

The fruit samples used in this study are safe for consumption except (P. kschum) which showed a high concentration of $\mathrm{Cr}$ and high cancer risk rendering it unsafe for consumption. The findings on the ADI, $\mathrm{HQ}$, and $\mathrm{HI}$ revealed that consumption of G. latifolium could pose CRs to human health due to the high concentration of $\mathrm{Cu}, \mathrm{Ni}, \mathrm{Cr}, \mathrm{Cd}$, and manganese.

\section{COMPETING INTEREST}

The authors hereby declare no conflicts of interest regarding the publication of this investigation.

\section{AUTHOR'S CONTRIBUTIONS}

All authors contributed equally.

\section{REFERENCES}

1. Järup L. Hazards of heavy metal contamination. Br Med Bull 2003;68:167-82.

2. Divrikli U, Horzum N, Soylak M, Elci L. Trace heavy metal contents of some spices and herbal plants from western Anatolia, Turkey. Int J Food Sci Technol 2013;41:712-6.

3. Sobukola OP, Adeniran OM, Odedairo AA, Kajihausa OE. Heavy metal levels of some fruits and leafy vegetables from selected markets in Lagos, Nigeria. Afr J Food Sci 2007;4:389-93.

4. Yusuf AA, Arowolo TA, Bamgbose O. Cadmium, copper and nickel levels in vegetables from industrial and residential areas of Lagos city, Nigeria. Food Chem Toxicol 2003;41:375-8.

5. Türkdoğan MK, Kilicel F, Kara K, Tuncer I, Uygan I. Heavy metals in soil, vegetables and fruits in the endemic upper gastrointestinal cancer region of Turkey. Environ Toxicol Pharmacol 2003;13:175-9.

6. Czarnek K, Terpiłowska S, Siwicki AK. Selected aspects of the action of cobalt ions in the human body. Cent Eur J Immunol 2015;40:236-42.

7. Sajjad K, Robina F, Shagufta S, Mohammed AK, Maria S. Health risk assessment of heavy metals for population via consumption of vegetables. World Appl Sci J 2009;6:1602-6.

8. Tsafe AI, Hassan LG, Sahabi DM, Alhassan Y, Bala BM. Evaluation of heavy metals uptake and risk assessment of vegetables grown in Yargadama of Northern Nigeria. J Basic Appl Sci Res 2012;2:6708-14.

9. Benson NU, Ebong GA. Heavy metals in vegetables commonly grown in a tropical garden ultisol. J Sustain Trop Agric Res 2005;16:77-80.

10. Khadeeja R, Sobin A, Umer R, Muhammad I, Saadia H, Tehreema I, et al. Comparison of proximate and heavy metal contents of vegetables grown with fresh and wastewater. Pak J Bot 2013;45:391-40.

11. Nwachukwu MA, Feng H, Allinor J. Assessment of heavy metal pollution in soil and their implications within and around mechanic villages. Int J Environ Sci Technol 2010;7:347-58.

12. Opaluwa OD, Aremu MO, Ogbo LO, Magaji JI, Odiba IE, Ekpo EK. Assessment of heavy metals in water, fish and sediments from UKE stream, Nasarawa state, Nigeria. Curr World Environ 2012;7:213-20.

13. Chishti KA, Khan FA, Hassan SS. Estimation of heavy metals in the seeds of blue and white capitulum's of Silybum marianum grown in various districts of Pakistan. J Basic Appl Sci 2011;7:45-9.

14. Liehr JG, Jones JS. Role of iron in estrogen-induced cancer. Curr Med Chem 2001;8:839-49.
15. Silbergeld EK. Facilitative mechanisms of lead as a carcinogen. Mutat Res 2003;533:121-33.

16. Neal AP, Guilarte TR. Mechanisms of heavy metal neurotoxicity: Lead and manganese. J Drug Metab Toxicol 2012;S5:1-13.

17. Manahan SE. Toxicological Chemistry and Biochemistry. $3^{\text {rd }}$ ed. Boca Raton: CRC Press, Limited Liability Company (LLC); 2003.

18. Scragg A. Environmental Biotechnology. $2^{\text {nd }}$ ed. Oxford, UK: Oxford University Press; 2006.

19. Osma E, Serin M, Leblebici Z, Aksoy A. Heavy metals accumulation in some vegetables and soils in Istanbul. Ekoloji 2012;21:1-8.

20. Idodo-Umeh G, Ogbeibu E. Bioaccumulation of heavy metals in cassava tubers and plantain fruits grown in soils impacted with petroleum and non-petroleum activities. Resour J Environ Sci 2010;4:33.

21. World Health Organization/Food and Agriculture Organization. Codex Alimentarius Commission. Food Additives and Contaminants. Joint FAO/WHO Food Standards Programme. No. ALINORM 01/12A; 2001. p. 1-289.

22. Ali Z, Hadi R, Amir HM. Health risk assessment of heavy metals in vegetables in an endemic esophageal cancer region in Iran. Health Scope 2018;7:e12340.

23. USEPA. Treatment Technologies for Site Cleanup: An Annual Status Report 2007. $12^{\text {th }}$ ed. Washington, DC, USA: Solid Waste and Emergency Response (5203P); 2010.

24. Wang X, Sato T, Baoshan X. Health risk of heavy metals to the general public of Tianjin, China via consumption of vegetables and fish. Sci Total Environ 2005;350:28-37.

25. Gezahegn WW, Srinivasulu A, Aruna, B, Banerjee S, Sudarshan M, Narayana PV, et al. Study of heavy metals accumulation in leafy vegetables of Ethiopia. IOSR J Environ Sci Toxicol Food Technol 2017;11:57-68.

26. Mwegoha WJ, Kihampa C. Heavy metal contamination in agricultural soils and water in Dar es Salaam city, Tanzania. Afr J Environ Sci Technol 2010;4:763-9.

27. Alam MG, Snow ET, Tanaka A. Arsenic and heavy metal contamination of vegetables grown in Samta village, Bangladesh. Sci Total Environ 2003;308:83-96.

28. Singh A, Sharma RK, Agrawal M, Marshall FM. Risk assessment of heavy metal toxicity through contaminated vegetables from wastewater irrigated area of Varanasi, India. Int Soc Trop Ecol 2007;51:375-87.

29. Jaishankar M, Mathew BB, Shah MS, Gowda KR. Biosorption of few heavy metal ions using agricultural wastes. J Environ Pollut Hum Health 2014;2:1-6.

30. Kim HL, Seo YR. Molecular and genomic approach for understanding the gene-environment interaction between Nrf2 deficiency and carcinogenic nickel-induced DNA damage. 2012;28:1959-67.

31. Díez S, Delgado S, Aguilera I, Astray J, Pérez-Gómez B, Torrent M, et al. Prenatal and early childhood exposure to mercury and methylmercury in Spain, a high-fish-consumer country. Arch Environ Contam Toxicol 2009;56:615-22.

32. Nguta JM. Essential Trace Elements: Trace Elements in Human and Animal Health. Saarbrücken, Germany: LAP, Lambert Academic Publishing; 2010.

33. USDOE. The Risk Assessment Information System (RAIS). Oak Ridge, TN, USA: U.S. Department of Energy Oak Ridge Operations Office (ORO); 2011.

34. Gowd SS, Reddy MR, Govil PK. Assessment of heavy metal contamination in soil at Jajmau (Kanpur) and unnao industrial areas of the Ganga plain, Uttar Pradesh, India. J Hazardous Mater 2010;174:113-21.

35. Adewole MB, Uchegbu LU. Properties of soils and plants uptake within the vicinity of selected automobile workshops in Ile-Ife, Southwestern Nigeria. Ethiop J Environ Stud Manage 2010;3:23-8. 
36. Vupputuri S, He J, Muntner P, Bazzano LA, Whelton PK, Batuman V. Blood lead level is associated with elevated blood pressure in blacks. Hypertension 2003;41:463-8.

37. Li Z, Zhang D, Wei Y, Luo L, Dai T. Risk assessment of trace elements is cultured from freshwater fishes from Jiangxi Provence, China. Environ Monit Assess 2014; 186:2185-94.

38. Salgueiro MJ, Zubillaga M, Lysionek A, Sarabia M, Caro R. Zinc as an essential micronutrient. Nutr Res 2000;20:737-55.

39. Krezel A, Maret W. Different redox states of metallothionein/thionein in biological tissue. Biochem J 2007;402:551-8.

40. Gyorffy EJ, Chan H. Copper deficiency and microcytic anemia resulting from prolonged ingestion of over-the-counter zinc. Am J Gastroenterol 1992;87:1054-5.
41. Prasad AS. Discovery of human zinc deficiency: 50 years later. J Trace Elements Med Biol 2012;26:66-9.

42. Adah CA, Abah J, Ubwa ST, Ekele S. Soil availability and uptake of some heavy metals by three staple vegetables commonly cultivated along the South bank of river benue, Makurdi, Nigeria. Int J Environ Bioenerg 2013;8:56-67.

\section{How to cite this article:}

Uroko IR, Okpashi VE, Oluomachi UN, Paulinus NC, Nduka

FO, Precious O. Evaluation of heavy metals in selected fruits

in Umuahia market, - Nigeria: Associating toxicity to effect for improved metal risk assessment. J App Biol Biotech. 2019;7(04):39-45.

DOI: 10.7324/JABB.2019.70407 